Research article

\title{
ASSESSMENT OF RENAL FUNCTION USING CANINE CYSTATIN-C LEVELS IN CANINE BABESIOSIS AND EHRLICHIOSIS
}

\author{
PEKMEZCI Didem ${ }^{1 *}$, URAL Kerem², AYSUL Nuran ${ }^{3}$, GUZEL Murat ${ }^{1}$, \\ CIFTCI Gulay ${ }^{4}$
}

${ }^{1}$ Department of Internal Medicine, Faculty of Veterinary Medicine, University of Ondokuz Mayis,
55139 Samsun/Turkey; ${ }^{2}$ Department of Internal Medicine, Faculty of Veterinary Medicine,
University of Adnan Menderes, 09016 Aydin/Turkey; ${ }^{3}$ Department of Parasitology, Faculty of
Veterinary Medicine, University of Adnan Menderes, 09016 Aydin/Turkey; ${ }^{4}$ Department of
Biochemistry, Faculty of Veterinary Medicine, University of Ondokuz Mayis, 55139 Samsun/Turkey

(Received $5^{\text {th }}$ May; Accepted 22 $2^{\text {nd }}$ September 2014)

\begin{abstract}
The purpose of the present study was to evaluate serum canine Cystatin-C (Cys-C) concentration for the prediction of renal function (RF) in dogs naturally infected with Babesia canis vogeli and Ehrlichia canis. A total of 46 dogs were enrolled into three groups. Group B included 16 dogs naturally infected with B. c. vogeli, group E 10 dogs naturally infected with E. canis [dogs diagnosed as canine monocytic ehrlichiosis (CME)], and group $\mathrm{H}$ involved 20 healthy controls (negative for B. c. vogeli and E. canis). Solely dogs presenting uncomplicated babesiosis caused by B. c. vogeli were enrolled. Serum urea and serum creatinine (Cre) levels with serum Urea:Cre ratios were analyzed. Canine serum Cys-C was determined with a species-specific commercially available and validated ELISA assay as a reference. Mean serum Cys-C levels were $5.28 \mathrm{mg} / \mathrm{L}, 3.02 \mathrm{mg} / \mathrm{L}$, and $2.30 \mathrm{mg} / \mathrm{L}$ for groups $\mathrm{B}, \mathrm{E}$ and $\mathrm{H}$, respectively. RF in uncomplicated CB caused by B. c. vogeli seems to be affected based on serum Cys-C concentrations. To the author's knowledge, this is the first study reporting that mean serum canine Cys-C levels in dogs with CME demonstrated no elevation. Serum canine Cys- $C$ as a novel RF marker could be used for early detection of renal injury in both babesiosis and CME.
\end{abstract}

Key words: Renal function, Cystatin-C, Canine, Babesia canis vogeli, Ehrlichia canis

\section{INTRODUCTION}

Canine babesiosis $(\mathrm{CB})$ is a protozoan disease caused by infection with tick-borne parasites of the genus Babesia with a worldwide distribution and global significance. There are 5 species of this genus infecting dogs, i.e., Babesia canis, B. vogeli, B. rossi, B. gibsoni, and B. conradae [1]. The 3 former species are large forms and the 2 latter species are small forms of Babesia spp in dogs. The most severe form of babesiosis is caused

Corresponding author: e-mail: dkazanci@omu.edu.tr 
by infection with B. rossi, while B. vogeli is considered the least pathogenic [2]. Clinical signs associated with babesiosis frequently involve lethargy, anorexia, pale mucous membranes, hyperthermia, hemolytic anaemia, hemoglobinuria, and icterus [3].

$\mathrm{CME}$ is an infectious disease caused by the rickettsial organism E. canis that affects mainly domestic dogs [4]. CME is another important canine vector-borne disease with a worldwide distribution. Infected animals with ehrlichiosis present several clinical signs that may vary depending on the stage of the disease [5]. The most frequent signs consist of high fever, anorexia, emaciation, hepatomegaly, splenomegaly, lymphadenopathy, cardiac and respiratory disturbance and nervous and ocular alterations [6]. The manifestations of the disease may be affected by the pathogenicity of different E. canis strains and co-infections with other arthropod-borne pathogens such as B. vogeli and Hepatozoon canis transmitted by the same vector [7].

Acute renal failure may be a severe complication of infection by several species of Babesia, with a prevalence varying from $2.2 \%$ to $36 \%$ [8-11]. However, pre-renal azotemia could not be excluded in some of those cases [9]. There is enough evidence to suggest that renal dysfunction is a serious complication associated with $\mathrm{CB}$ that has been shown to influence the outcome [12,13]. Therefore, sensitive markers are necessary for the early diagnosis of renal dysfunction in CB. Contrary to babesiosis, scarce reports suggest that E. canis may be a cause of renal dysfunction. Codner et al. [14] indicated a possible glomerulopathy with minimal changes and without histologic evidence of glomerular disease could be seen during acute E. canis infection. Therefore, limited information is available regarding the potential diagnostic or prognostic value of renal markers for this disease in dogs.

In veterinary clinical practice, serum urea and Cre concentrations are widely used as endogenous markers for evaluating RF in dogs and cats because they are easy and inexpensive to perform [15]. Serum Urea is more likely to increase due to pre-renal factors than serum Cre, whereas both parameters are equally likely to increase due to renal diseases [16]. On the other hand, serum Cre usually only becomes elevated once more than $75 \%$ of RF is lost.

Serum urea and Cre values can also be influenced by extra-renal factors. Over several years serum levels of Cys- $C$ have been considered as a significant marker for filtration rate, and the blood protein $\mathrm{Cys}-\mathrm{C}$ is believed to be an important endogenous marker of RF [17]. Cys-C is a low molecular weight $(14 \mathrm{kD})$ basic protein of the cystatin super family, inhibitors of cystein-proteases, which is produced at a constant rate by all nucleated cells [18]. Therefore, it is freely filtered by the renal glomerulus, and entirely catabolized in the proximal tubule [19]. Its filtration is unchanged in kidney tubular diseases where its urinary excretion is increased [19]. Cys-C plasma concentration is thus mainly dependent on the glomerular filtration rate (GFR) [20, 21].

Therefore, the purpose of the current study was to predict RF in dogs with babesiosis and ehrlichiosis, by use of indirect serum markers of the reduction of GFR plus a 
novel biomarker, serum Cys-C, which was measured with species-specific commercially available and validated ELISA assay as a reference.

\section{MATERIALS AND METHODS}

\section{Animals}

A total of 46 mixed breed, 1 to 6 years old dogs of different sex and weights between 16 and $40 \mathrm{~kg}$ were enrolled in the study and divided into three groups. Group B included 16 dogs naturally infected with B. c. vogeli, group E included 10 dogs naturally infected with E. canis, and group $\mathrm{H}$ included 20 controls that were negative for $B$. $c$. vogeli and E. canis. Enrolled cases did not have detectable co-infections (Anaplasmosis, Leishmaniasis, and Lyme disease were excluded based on rapid diagnostic ELISA test kits (SNAP 4Dx ${ }^{\circledR}$, IDEXX Laboratories, USA), blood smear and cytology, and available IFAT/PCR results). None of the healthy dogs had a history or clinical signs consistent with any of the diseases prior to sampling. Dogs with concurrent diseases were excluded from the study. The animals were treated according to the Animal Care and Use Regulation (European Convention for the Protection of Vertebrate Animals Used for Experimental and Other Scientific Purposes 1996).

\section{Samples}

Venous blood was taken from the cephalic vein, evacuated into a $2 \mathrm{ml}$ plain tube with K3 EDTA $(7.5$ per cent $0.040 \mathrm{ml})$ for blood count evaluations, and $10 \mathrm{ml}$ into a Vacutainer without anticoagulant for biochemical analysis. Samples collected into plain tubes were centrifuged at $3000 \mathrm{~g}$ for $10 \mathrm{~min}$ at room temperature. Later, serum samples were separated and stored at $-80^{\circ} \mathrm{C}$ until analysis. Collected blood samples in EDTA tubes were stored at $-80{ }^{\circ} \mathrm{C}$ until DNA was extracted.

\section{Determination of B. canis vogeli infection}

The diagnosis of babesiosis was confirmed by direct observation of the protozoa in the blood smears. The identity of the Babesia spp. responsible for the infection was confirmed by polymerase chain reaction (PCR) and reverse line blot (RLB). PCR was also used to exclude co-infection with E. canis. Only dogs presented with uncomplicated babesiosis caused by B. c. vogeli were included in this study. Uncomplicated babesiosis was defined as a clinical presentation attributable to hemolytic anemia only [10]. DNA from frozen blood $(200 \mu \mathrm{l})$ was extracted using the Wizard ${ }^{\mathbb{B}}$ Genomic DNA Purification Kit (Promega Corporation, Madison, USA). A couple of primer sets was used for PCR. The forward primer RLB-F2 (5'-GACACAGGGAGGTAGTGACAAG-3') and the reverse primer RLB-R2 (biotin-5'-CTAAGAATTTCACCTCTGACAGT-3') were used for the amplification regions conserved for Babesia and Theileria (Table 1) [22]. 
RLB was performed using PCR products as described by Gubbels et al. [22] and Matjila et al. [23].

Table 1. Primer set used for PCR for diagnosis B. c. vogeli

\begin{tabular}{llc}
\hline Species specific oligonucleotide & Sequence (5'-3') & Dilutions \\
\hline Theileria/Babesia (Catchall) & TAATGGTTAATAGGARCRGTTG & $50 \mathrm{pmol}$ \\
B. c. rossi & CGGTTTGTTGCCTTTTGTG & $200 \mathrm{pmol}$ \\
B. c. vogeli & AGCGTGTTCGAGTTTGCC & $400 \mathrm{pmol}$ \\
B. c. canis & TGCGTTGACGGTTTGAC & $400 \mathrm{pmol}$ \\
\hline
\end{tabular}

\section{Determination of E. canis infection}

Blood smear evaluation was positive for all cases enrolled. DNA extraction was performed according to commercial High Pure PCR Template Preparation Kit ${ }^{\circledR}$ (Roche Diagnostics, Mannheim, Germany). DNA was extracted from $300 \mathrm{ml}$ of frozen whole blood. Amplification PCR was made as described previously by Breitschwerdt et al. [24]. Briefly, a $50 \mathrm{ml}$ reaction mixture contained $1 \mu \mathrm{g}$ of template DNA; 200 $\mathrm{mM}$ (each) dATP, dTTP, dCTP, and dGTP; 0.05 pmol (each) of the outer primers designated EHR-OUT1 and EHR-OUT2, 12.5 pmol (each) of the inner primers designated GE2f and EHRL3-IP2. Each sample belonging to group E was tested by the use of an ELISA kit (SNAP 4Dx ${ }^{\circledR}$, IDEXX Laboratories, USA) as described previously [25]. Aforementioned canine point-of-care ELISA kit detects antibodies of immunodominant proteins of E. canis (p30 and p30-1) [25].

\section{Serum biochemical analyzes}

Serum Urea levels were analyzed within urease UV principle Spinreact ${ }^{\circledR}$ kits (Cat. No.: 1001332, Spain) and serum Cre levels were analyzed within Jaffe Reaction principle Spinreact ${ }^{\circledR}$ kits (Cat. No.: 1001110, Spain) in Tokyo Boeki TMS 1024 model automate biochemical analyzer. Serum canine $\mathrm{Cys-C}$ levels were measured by sandwich enzyme immunoassay method using Canine Cystatin- ${ }^{\circledR}$ ELISA kit (BioVendor, Cat. No.: RD491009100R, Czech Republic) according to the manufacturers instructions. All samples were measured on a spectrophotometer (Digital and Analog Systems S.R.L.) at $450 \mathrm{~nm}$.

\section{Statistical analysis}

Data were analyzed by the analysis of variance (ANOVA) means compared by the Tukey test of SAS. Data are expressed as mean \pm standard deviation (SD). $P<0.001$ was assumed as significant. 


\section{RESULTS}

Babesia canis vogeli and E. canis infected dogs both presented with suggestive clinical signs of the diseases. Dogs infected with B. c. vogeli presented clinical signs involving pale mucous membranes, depression, anorexia, weakness, splenomegaly, tachycardia, tachypnoea, and fever. Depression, lethargy, anorexia, pyrexia and lymphadenopathy were the main clinical signs in dogs with CME. A summary of the descriptive statistics of the mean serum urea, Cre, Urea:Cre ratios and Cys-C, data is provided in Table 2. Dogs in group $\mathrm{H}$ presented an elevated mean serum urea $(71.85 \mathrm{mg} / \mathrm{dl})$, whereas dogs in groups $B$ and $E$ had a median serum urea within the reference range $(16-54 \mathrm{mg} / \mathrm{dl})$. The mean serum Cre value, reference range $0.5-1.4 \mathrm{mg} / \mathrm{dl}$, was $1.78 \mathrm{mg} / \mathrm{dl}$ in group B, 1.53 $\mathrm{mg} / \mathrm{dl}$ in group $\mathrm{E}$, and $1.45 \mathrm{mg} / \mathrm{dl}$ in group $\mathrm{H}$, with no statistical significance between the three groups. An elevated serum Urea:Cre ratio was evident in all groups, and dogs in group $\mathrm{H}$ had a statistically significant difference $(P<0.001)$ compared with groups B, and E. Mean serum Cys-C levels were $5.28 \mathrm{mg} / \mathrm{L}$ (group B), $3.02 \mathrm{mg} / \mathrm{L}$ (group E), and $2.30 \mathrm{mg} / \mathrm{L}$ (group H). Dogs in group B showed the highest values. There was a statistically significant difference $(P<0.001)$ between group $\mathrm{B}$ and the other groups for mean serum Cys-C levels.

Table 2. Summary of serum chemistry data in Babesia (B) and Ehrlichia (E) infected, and healthy $(\mathrm{H}) \operatorname{dogs}$

\begin{tabular}{lccccccc}
\hline Variable & Group & N & Mean & SD & $\begin{array}{c}\text { Range } \\
\text { (min-max) }\end{array}$ & F value & P-value \\
\hline \multirow{2}{*}{ Urea $(\mathrm{mg} / \mathrm{dl})$} & $\mathrm{B}$ & 16 & $35.99^{\mathrm{a}}$ & 12.04 & $21.60-74.90$ & & \\
& $\mathrm{E}$ & 10 & $40.87^{\mathrm{a}}$ & 12.61 & $21.40-55.64$ & 27.05 & 0.000 \\
& $\mathrm{H}$ & 20 & $71.85 \mathrm{~b}$ & 19.03 & $34.00-97.00$ & & \\
\hline \multirow{2}{*}{ Cre $(\mathrm{mg} / \mathrm{dl})$} & $\mathrm{B}$ & 16 & 1.78 & 0.43 & $1.00-2.56$ & & \\
& $\mathrm{E}$ & 10 & 1.53 & 0.51 & $0.70-2.69$ & 1.62 & 0.209 \\
\hline \multirow{2}{*}{ Urea:Cre ratio } & $\mathrm{H}$ & 20 & 1.45 & 0.66 & $0.70-2.90$ & & \\
(mg/dl) & $\mathrm{E}$ & 16 & $20.45^{\mathrm{a}}$ & 5.22 & $13.38-31.60$ & & \\
& $\mathrm{H}$ & 20 & $29.38^{\mathrm{a}}$ & 14.93 & $14.65-64.20$ & 16.36 & 0.000 \\
\hline \multirow{2}{*}{ Cys-C $(\mathrm{mg} / \mathrm{L})$} & $\mathrm{B}$ & 16 & $5.28 \mathrm{~b}$ & 29.93 & $13.33-127.14$ & & \\
& $\mathrm{E}$ & 10 & $3.02^{\mathrm{a}}$ & 1.66 & $2.43-7.45$ & & \\
\hline
\end{tabular}

For each parameter, differences in lower case superscript letters in the same column indicate significant differences $(P<0.001)$ between groups.

\section{DISCUSSION}

Immunopathological mechanisms during the course of $\mathrm{CB}$ result in systemic inflammatory response syndrome, multiple organ dysfunction syndrome, haemolysis, and other complications [26]. Injury of the liver, kidney, lungs, pancreas, heart, and brain has been described during the course of $\mathrm{CB}[27,28]$. 
During the subclinical phase no clinical signs are evident in CME [29]. For reasons still unclear, certain dogs will progress to the chronic phase of CME. During the chronic phase, signs similar to those seen in the acute phase may occur but with a greater severity. Pale mucous membranes and weakness, bleeding and significant weight loss are common findings in this phase [30]. Contrary to $\mathrm{CB}$, renal signs are less often described in CME.

Diagnostic modalities such as kidney biopsies could have helped to determine the significance of the changes in this study. However, since this study was performed under clinical conditions it was not ethically possible to perform invasive procedures such as serial kidney biopsies in client-owned dogs.

Traditionally, biochemical evidence of renal insufficiency is documented with elevations in serum urea and Cre $[28,31]$. Their reciprocal plots roughly correlate with GFR [31]. Both urea and Cre require about 60-75\% loss of nephron function before they became elevated [31]. To increase their specificity, serum urea and Cre are often tested concurrently [32]. In renal disease they are expected to behave similarly with both parameters increasing as GFR decreases [32]. Therefore, serum urea and Cre will only increase when more than $75 \%$ of renal functional mass is lost, making them insensitive markers for early detection of renal dysfunction [27].

Pigmented serum, especially free haemoglobin and/or bilirubin due to haemolysis, is a common finding in dogs with babesiosis, resulting in interference with the biochemical tests that rely on photochemistry [16]. One of the biochemical tests is the spectrophotometric analysis of Cre which interferes with bilirubin and haemoglobin. In contrast to Cre, addition of albumin, bilirubin and haemoglobin did not substantially interfere with the measurement of $\mathrm{Cys}-\mathrm{C}$ in the urine [33]. Moreover, studies conducted on the potential interference of bilirubin, haemoglobin and lipemia in the plasma and sera showed that Cys- $\mathrm{C}$ measurement was neither interfered with by icterus nor by haemolysis [34].

In the current study mean serum urea concentrations were above the reference limit (16$54 \mathrm{mg} / \mathrm{dl})$ only in group $\mathrm{H}(71.85 \mathrm{mg} / \mathrm{dl})$ with the presence of normal mean serum Cre $(1.45 \mathrm{mg} / \mathrm{dl})$ and Cys-C $(2.30 \mathrm{mg} / \mathrm{L})$ concentrations. There was a statistical significance $(P<0.001)$ obtained among groups for the mean serum urea concentrations. The reason for elevated mean urea levels might be due to non-renal factors in group $\mathrm{H}$, resulting in an elevated serum Urea:Cre ratio. However, in the present study the cause of elevated Urea:Cre ratio remains undetermined. Recent food over consumption may be a reason of this hyperureagenesis. Other ammonia loading reasons such as, haemolysis, blood transfusions, and gastro-intestinal hemorrhage [35,36] were all absent in the observed dogs. However, mean serum Cre levels were above the reference limit $(0.5-1.4 \mathrm{mg} / \mathrm{dl})$ in group $B(1.78 \mathrm{mg} / \mathrm{dl})$, and $\mathrm{E}(1.53 \mathrm{mg} / \mathrm{dl})$. No statistical significance $(P=0.209)$ was obtained among study groups for mean serum Cre levels. Distinctly, group $\mathrm{H}$ had a higher value of mean serum Urea:Cre ratio $(59.46 \mathrm{mg} / \mathrm{dl})$ with a statistical significance $(P<0.001)$ between the groups. In human medicine azotemic patients with a serum 
Urea:Cre ratio of $\geq 20$ indicates pre-renal azotemia, whereas a serum Urea:Cre ratio of $<20$ presents intrinsic renal disease [37]. The increase of serum Urea:Cre ratio in group $\mathrm{H}$ might be due to the ammonia loading as described before. De Scally et al. [16] indicate that serum urea is more likely to increase due to pre-renal factors than serum Cre, whereas both parameters are equally likely to increase due to renal problems. De Scally et al. [32] hypothesized that some dogs in babesiosis with high serum urea and low or normal Cre concentrations may have had renal azotemia. However, a later study by De Scally et al. [16] concluded that elevated serum Urea concentrations in $\mathrm{CB}$ in the absence of elevated serum Cre concentrations were not likely to be of renal origin, since serum Cys- $\mathrm{C}$ concentrations were not elevated in study dogs with normal serum Cre concentrations. On the comtrary, neither mean serum urea (35.99 $\mathrm{mg} / \mathrm{dl})$ nor mean serum Urea:Cre ratio $(20.45 \mathrm{mg} / \mathrm{dl})$ in group B were elevated in our study. On the other hand, mean serum Cys-C levels in group B $(5.28 \mathrm{mg} / \mathrm{L})$ was found significantly different $(P<0.001)$ when compared to group E $(3.02 \mathrm{mg} / \mathrm{L})$ and group $\mathrm{H}(2.30 \mathrm{mg} / \mathrm{L})$. The findings of the present study are consistent with the previous researches that report renal dysfunction as a serious complication associated with CB $[27,28]$. Although, some urinary markers with $\mathrm{Cys}-\mathrm{C}$ were analyzed in various researches on $\mathrm{CB}$, renal effects of $\mathrm{CME}$ were not discussed.

Frank and Breitschwerdt [38] found azotemia in a small percentage of cases, with elevated blood urea nitrogen in 13 dogs and elevated serum creatinine concentration in 7 dogs in a retrospective study of ehrlichiosis in 62 dogs. With the exception of mean serum urea level $(40.87 \mathrm{mg} / \mathrm{dl})$ in group E, our results with increased mean serum Urea:Cre ratio $(29.38 \mathrm{mg} / \mathrm{dl})$, and mean serum Cre $(1.53 \mathrm{mg} / \mathrm{dl})$ levels were in accordance previously published [38] results. On the other hand, mean serum Cys-C $(3.02 \mathrm{mg} / \mathrm{L})$ level in group $\mathrm{E}$ indicated that RF in CME does not seem to be affected.

In conclusion, our results demonstrate that RF in uncomplicated $\mathrm{CB}$ caused by $B$. $c$. vogeli seems to be affected based on serum $C y s-C$ concentrations. Contrarily, RF in CME does not seem to be affected by $\mathrm{CB}$. The present manuscript is a preliminary study representing mean serum canine $\mathrm{Cys}-\mathrm{C}$ levels in dogs with $\mathrm{CME}$. Furthermore, serum urea, and Urea:Cre ratio concentrations should not be used as indicators of RF in $\mathrm{CB}$ and $\mathrm{CME}$. Serum canine Cys-C, as a novel RF marker, might be used for early detection of renal injury in both $\mathrm{CB}$ and $\mathrm{CME}$.

\section{Acknowledgements}

The authors wish to thank Dr. Gokmen Zafer Pekmezci for his valuable help and support for preparing this manuscript.

\section{REFERENCES}

1. Zygner W, Gójska-Zygner O, Wędrychowicz H: Strong monovalent electrolyte imbalances in serum of dogs infected with Babesia canis. Ticks Tick Borne Dis 2012, 3: 107-113. 
2. Irwin PJ: Canine babesiosis: from molecular taxonomy to control. Parasit Vectors 2009, 2: S4.

3. Bourdoiseau G : Canine babesiosis in France. Vet Parasitol 2006, 138: 118-125.

4. Huxsoll DL, Hildebrandt PK, Nims RM, Walker JS: Tropical canine pancytopenia. J Am Vet Med Assoc 1970, 157: 1627-1632.

5. De Castro MB, Machado RZ, de Aquino LP, Alessi AC, Costa MT: Experimental acute canine monocytic ehrlichiosis: clinicopathological and immunopathological findings. Vet Parasitol 2004, 119: 73-86.

6. Troy GC, Forrester SD: Canine Ehrlichiosis. In: Infectious Diseases of the Dog and Cat. W.B. Saunders, Philadelphia; 1990, 48-59.

7. Gal A, Harrus S, Arcoh I, Lavy E, Aizenberg I, Mekuzas-Yisaschar Y, Baneth G: Coinfection with multiple tick-borne and intestinal parasites in a 6-week-old dog. Can Vet J 2007, 48: 619-622.

8. Camacho AT, Guitian EJ, Pallas E, Gestal JJ, Olmeda AS, Goethert HK, Telford 3rd SR, Spielman A: Azotemia and mortality among Babesia microti-like infected dogs. J Vet Intern Med 2004, 18: 141-146.

9. Garcia AT: Piroplasma infection in dogs in northern Spain. Vet Parasitol 2006, 138, 97-102.

10. Jacobson L J, Clark I: The pathophysiology of canine babesiosis: new approaches to an old puzzle. J S Afr Vet Assoc 1994, 65: 134-145.

11. Máthé A., Vörös K, Papp L, Reiczigel J: Clinical manifestations of canine babesiosis in Hungary (63 cases). Acta Vet Hung 2006, 54: 367-385.

12. Lobetti RG, Jacobson LS: Renal involvement in dogs with babesiosis. J S Afr Vet Assoc 2001, 72: 23-28.

13. Welzl C, Leisewitz AL, Jacobson LS, Vaughan-Scott T, Myburgh E: Systemic inflammatory response syndrome and multiple-organ damage/dysfunction in complicated canine babesiosis. J S Afr Vet Assoc 2001, 72: 158-162.

14. Codner EC, Caceci T, Saunders GK, Smith CA, Robertson JL, Martin RA, Troy GC: Investigation of glomerular lesions in dogs with acute experimentally induced Ehrlichia canis infection. Am J Vet Res 1992, 53: 2286-2291.

15. Miyagawa Y, Takemura N, Hirose H: Evaluation of the measurement of serum cystatin $\mathrm{C}$ by an enzyme-linked immunosorbent assay for humans as a marker of the glomerular filtration rate in dogs. J Vet Med Sci 2009, 71: 1169-1176.

16. De Scally MP, Leisewitz AL, Lobetti RG, Thompson PN: The elevated serum urea:creatinine ratio in canine babesiosis in South Africa is not of renal origin? J S Afr Vet Assoc 2006, 77: 175-178.

17. Antognoni MT, Siepi D, Porciello F, Fruganti G: Use of serum cytatin C determination as a marker of renal function in the dog. Vet Res Comm 2005, 29: 265-267.

18. Antognoni MT, Siepi D, Porciello F, Rueca F, Fruganti G: Serum cystatin-C evaluation in dogs affected by different diseases associated or not with renal insufficiency. Vet Res Comm 2007, 31: 269-271.

19. Braun JP, Perxachs A, Pechereau D, De La Farge F: Plasma cystatin C in the dog: reference values and variations with renal failure. Comp Clin Pathol 2002, 11: 44-49.

20. Randers E, Kristensen JH, Erlandsen EJ, Danielsen H: Serum cystatin C as a marker of renal function. Scand J Clin Lab Investig 1998, 58: 585-592.

21. Randers E, Erlandsen EJ: Serum cystatin $C$ as an endogenous marker of the renal function - A Review. Clin Chem Lab Med 1999, 37: 389-395. 
22. Gubbels JM, de Vos AP, van der Weide M, Viseras J, Schouls LM, de Vries E, Jongejan F: Simultaneous detection of bovine Theileria and Babesia species by reverse line blot hybridization. J Clin Microbiol 1999, 37: 1782-1789.

23. Matjila PT, Penzhorn BL, Bekker CP, Nijhof AM, Jongejan F: Confirmation of occurrence of Babesia canis vogeli in domestic dogs in South Africa. Vet Parasitol 2004, 122: 119-125.

24. Breitschwerdt B, Bhegarty EC, Hancock SI: Sequential evaluation of dogs naturally infected with Ehrlichia canis, Ehrlichia chaffeensis, Ehrlichia equi, Ehrlichia ewingii, or Bartonella vinsonii. J Clin Microbiol 1999, 36: 2645-2651.

25. Carrade D, Foley J, Sullivan M, Foley CW, Sykes JE: Spatial distribution of seroprevalence for Anaplasma phagocytophilum, Borrelia burgdorferi, Ehrlichia canis, and Dirofilaria immitis in dogs in Washington, Oregon, and California. Vet Clin Pathol 2011, 40: 293-302.

26. Matijatko V, Kis I, Torti M, Brkljaci'c M, Kucer N, Bari'c Rafaj R, Grden D, Zivicnjak T, Mrljak V: Septic shock in canine babesiosis. Vet Parasitol 2009, 162: 263-270.

27. Defauw P, Schoeman JP, Smets P, Goddard A., Meyer E, Liebenberg C, Daminet, S: Assessment of renal dysfunction using urinary markers in canine babesiosis caused by Babesia rossi. Vet Parasitol 2012, 190: 326-332.

28. Di Bartola SP: Clinical approach and laboratory evaluation of renal disease. In: Textbook of veterinary internal medicine (5th edn). WB Saunders, Philadelphia; 2000, 1600-1614.

29. Waner T, Harrus S, Bark H, Bogin E, Avidar Y, Keysary A: Characterization of the subclinical phase of canine ehrlichiosis in experimentally infected beagle dogs. Vet Parasitol 1997, 69: 307-317.

30. Harrus S, Waner T, Bark H: Canine monocytic ehrlichiosis update. Compend Contin Educ Vet 1997, 19: 431-444.

31. Finco DR: Evaluation of renal function. In: Canine and Feline Nephrology and Urology. Williams and Wilkins, Philadelphia, USA; 1997, 216-229.

32. De Scally MP, Lobetti RG, Reyers F, Humphris D: Are urea and creatinine values reliable indicators of azotaemia in canine babesiosis? J S Afr Vet Assoc 2004, 75: 121-124.

33. Herget-Rosenthal S, Feldkamp T, Volbracht L, Kribben A: Measurement of urinary cystatin $\mathrm{C}$ by particle-enhanced nephelometric immunoassay: precision, interferences, stability and reference range. Ann Clin Biochem 2004, 41: 111-118.

34. Newman DJ, Thakkar H, Edwards RG, Wilkie M, White T, Grubb AO, Price CP: Serum cystatin $\mathrm{C}$ measured by automated immunoassay: a more sensitive marker of changes in GFR than serum creatinine. Kidney Int 1995, 47: 312-318.

35. Reyers F: Is azotaemia in canine babesiosis an indication of renal disease? In: Proceedings of the 9th Faculty Day. University of Pretoria, Faculty of Veterinary Science, 1992, 17.

36. Torbica G, Bedrica L, Samardžija M, Lipar M, Ljubojević D, Kreszinger M, Đuričić D, Harapin I. Canine babesiosis treatment with three different medicines. Acta Vet (Beograd) 2013, 63 (2-3): 279-290.

37. Isselbaher KJ, Braunwald E, Wilson JD: Acute renal failure. In: Harrison's Principles of internal medicine. McGraw-Hill, Columbus; 1994, 1265-1274.

38. Frank JR, Breitschwerdt EB: A retrospective study of ehrlichiosis in 62 dogs from North Carolina and Virginia. J Vet Intern Med 1999, 13: 194-201. 


\title{
PROCENA FUNKCIJE BUBREGA KOD BABEZIOZE I ERLIHIOZE PASA PREMA NIVOU CISTATIN-C
}

\author{
PEKMEZCI Didem, URAL Kerem, AYSUL Nuran, GUZEL Murat, CIFTCI Gulay
}

Cilj studije je bio evaluacija koncentracija Cistatin-C (Cys-C) u serumu pasa radi predviđanja funkcionalnog stanja bubrega (RF) pasa prirodno inficiranih sa Babesia canis vogeli i Ehrlichia canis. Ukupno 46 pasa bilo je podeljeno u tri grupe. Grupu B činilo je 16 pasa, prirodno inficiranih B. c. vogeli U grupi E bilo je10 pasa, prirodno inficiranih E. canis [psi kod kojih je dijagnostikovana monocitna erlihioza (ME)], dok se H grupa sastojala iz 20 zdravih (kontrolnih) pasa (negativni na B. c. vogeli i E. canis). Ispitivani su samo psi koji nisu imali komplikovane slučajeve babezioze, već samo babeziozu uzrokovanu B. c. vogeli. Analizirane su koncentracije ureje i kreatinina u serumu, kao i međusobni odnos ovih koncentracija (Urea:Cre). Cys-C u serumu pasa bio je određivan pomoću komercijalno dostupnog i validiranog referentnog ELISA dijagnostičkog testa specifičnog za vrstu. Srednje vrednosti Cys-C koncentracija u serumu bile su: za grupu B - 5,28 mg/L, za grupu E - 3,02 Mg/L i za grupu H $2,30 \mathrm{mg} / \mathrm{L}$. Na osnovu koncentracije Cys-C u serumu, uočava se da je funkcionalno stanje bubrega izmenjeno kod nekomplikovanih slučajeva babezioze pasa izazvanih B. c. vogeli. Prema saznanjima autora, radi se o prvoj studiji koja prikazuje da srednje vrednosti Cys- $C$ u serumu pasa nisu uvećane kod monocitne erlihioze pasa izazvane E. canis. Cys-C u serumu pasa može da se koristi kao marker funkcionalnog stanja bubrega, a za ranu detekciju oštećenja bubrega kod babezioze i monocitne erlihioze kod ove vrste životinja. 